Louisiana State University

LSU Digital Commons

Faculty Publications

Department of Biological Sciences

$12-1-1993$

\title{
Arabidopsis GLABROUS1 gene requires downstream sequences for function
}

J. C. Larkin

University of Minnesota Twin Cities

D. G. Oppenheimer

University of Minnesota Twin Cities

S. Pollock

University of Minnesota Twin Cities

M. D. Marks

University of Minnesota Twin Cities

Follow this and additional works at: https://digitalcommons.Isu.edu/biosci_pubs

\section{Recommended Citation}

Larkin, J., Oppenheimer, D., Pollock, S., \& Marks, M. (1993). Arabidopsis GLABROUS1 gene requires

downstream sequences for function. Plant Cell, 5 (12), 1739-1748. https://doi.org/10.1105/tpc.5.12.1739

This Article is brought to you for free and open access by the Department of Biological Sciences at LSU Digital Commons. It has been accepted for inclusion in Faculty Publications by an authorized administrator of LSU Digital Commons. For more information, please contact ir@lsu.edu. 


\title{
Arabidopsis GLABROUS1 Gene Requires Downstream Sequences for Function
}

\author{
John C. Larkin, ${ }^{1}$ David G. Oppenheimer, ${ }^{1}$ Susan Pollock, ${ }^{1}$ and M. David Marks ${ }^{2}$ \\ School of Biological Sciences, University of Nebraska-Lincoln, Lincoln, Nebraska 68588-0118
}

The Arabidopsis GLABROUS1 (GL1) gene is a myb gene homolog required for the initiation of trichome development. In situ hybridization revealed that the highest levels of GL1 transcripts were present in developing trichomes. In contrast, previous work had shown that putative promoter sequences from the $5^{\prime}$ noncoding region of the GL1 gene directed the expression of a $\beta$-glucuronidase (GUS) reporter gene only in stipules. Deletion analysis of the $3^{\prime}$ noncoding region of $G L 1$ has identified an enhancer that is essential for GL1 function. Sequences from the region containing the enhancer, in conjunction with GL1 upstream sequences, direct the expression of a GUS reporter gene in leaf primordia and developing trichomes in addition to stipules, indicating that the downstream enhancer is required for the normal expression pattern of GL1.

\section{INTRODUCTION}

A fundamental process during development is the commitment of cells to different developmental fates, a process known as determination (Slack, 1983; McDaniel, 1985). Determination can occur at several levels: cells may become committed to form a particular organ, tissue, or cell type. The differentiation of trichomes (hairs) on the epidermis of Arabidopsis shoots provides an excellent opportunity to study the commitment of cells to a specific pathway leading to a single, differentiated cell type (reviewed in Marks et al., 1991).

Arabidopsis trichomes are unicellular structures 200 to 500 $\mu \mathrm{m}$ in height, with a thickened cell wall and a papillate surface. They are found on the surfaces of leaves, sepals, petioles, and stems. Trichomes are not essential for viability, and mutations affecting trichome development have been isolated in 10 different genes (Koornneef et al., 1982; Haughn and Somerville, 1988; Marks and Esch, 1993). Multiple mutant alleles have been identified for most of these genes, indicating that most of the genes specifically involved in trichome development have been identified. Recessive mutations in two genes, GLABROUS1 (GL1) and TRANSPARENT TESTA, GLABRA (TTG), block the initiation of most trichomes. All known mutant alleles at the TTG locus are pleiotrophic; mutant plants lack seed coat mucilage and seed coat color as well as trichomes. All alleles of $G L 1$, including a null allele in which the entire gene is deleted (g/1-1; Oppenheimer et al., 1991), affect only trichome development.

\footnotetext{
1 Current address: Department of Genetics and Cell Biology, University of Minnesota, St. Paul, MN 55108.

${ }^{2}$ To whom correspondence should be addressed. Current address: 250 Biological Sciences, 1445 Gortner Avenue, University of Minnesota, St. Paul, MN 55108.
}

The GL1 gene has been cloned by T-DNA tagging (Herman and Marks, 1989; Marks and Feldmann, 1989). DNA sequence analysis revealed that the $\mathrm{N}$-terminal domain of the $G L 1$ gene product contained sequence similarity to the myb class of transcriptional regulators (Oppenheimer et al., 1991). Plant myb genes are usually present as gene families, although the functions of few plant $m y b$ genes have been determined to date (reviewed in Larkin et al., 1993).

The GL1 transcript is very low in abundance and has not been detected on RNA gel blots, although cDNAs have been isolated using polymerase chain reaction. When $1.4 \mathrm{~kb}$ of $5^{\prime}$ noncoding sequences containing the putative $G L 1$ promoter were fused to the $\beta$-glucuronidase (GUS) reporter gene and introduced into Arabidopsis plants, GUS activity in the vegetative meristem was detected only in paired stipulelike structures at the bases of the leaves. This result was unexpected, because the trichomes develop from cells on the protoderm of the leaf and not from the stipules.

The existence of additional regulatory sequences for GL1 was suggested by the nature of the gl/-43 mutant allele, the T-DNA-induced insertion allele that was used to clone the GL1 locus (Herman and Marks, 1989; Marks and Feldmann, 1989). The T-DNA insertion in the g/1-43 allele is located 581 bp downstream of the GL1 polyadenylation sites (Oppenheimer et al., 1991). This allele exhibits only a partial loss of GL1 function; no trichomes are found on the stems of mutant plants, but normal trichomes are present on leaves and sepals. The phenotype of this mutant indicated that some $G L 1$ regulatory sequences might be located downstream of the coding region. In this report, we demonstrate that GL1 transcripts are present in leaf primordia and developing trichomes. We have also identified an enhancer-like element located downstream of the 
GL1 transcribed region that is required for all GL1 functions. Sequences from the region containing the enhancer extend the range of expression of the GUS reporter gene directed by GL1 $5^{\prime}$ sequences to include expression in leaf primordia and developing trichomes.

\section{RESULTS}

\section{Localization of GL1 Transcripts}

The localization of GL1 transcripts by in situ hybridization is shown in Figure 1. Tissue sections were hybridized with antisense or sense strand digoxigenin-labeled RNA probes derived from the $3^{\prime}$ end of the GL1 coding region downstream of the conserved myb domain. This region of the GL1 gene has no significant DNA sequence similarity to any of the other Arabidopsis myb genes that we have sequenced, and the probe sequences are present in the Arabidopsis genome as a single copy, as determined by DNA blotting (D.G. Oppenheimer, unpublished data).

The strongest hybridization signal was detected in developing trichomes of the leaf and stem (Figures $1 \mathrm{~A}$ and $1 \mathrm{~B}$, filled arrows). Weak hybridization was also detected in other cells of the leaf, particularly in the adaxial epidermis (Figure 1C, white arrow). Occasional strongly hybridizing, unexpanded individual cells in the epidermis were observed (Figure 1C, filled arrow). These cells may represent trichome precursor cells.
No GL1 transcripts have been detected in mature stipules (Figures 1A and 1D, open arrows). However, low levels of GL1 transcripts have been observed in developing stipules, young floral primordia, developing stamens, and developing carpels (D. G. Oppenheimer, unpublished data). No hybridization was observed with the sense strand probe (Figure 1D).

\section{Identification of an Enhancer-Like Element Downstream of GL1 That Is Required for GL1 Function}

Because the stipule-specific expression pattern of the GUS reporter gene in plants containing a fusion of $1.4 \mathrm{~kb}$ of GL1 upstream sequences to the GUS coding region ( $p$ GL1p/GUS; Oppenheimer et al., 1991) does not accurately reflect the expression pattern of the GL1 transcript, additional regulatory sequences must be present at the GL1 locus. The structure of the g/1-43 allele suggested that sequences required for proper GL1 function are located downstream of the gene. To test for the presence of such sequences, two sets of nested deletions were constructed in the GL1 3 ' noncoding region, as shown in Figure 2. The starting point for both sets of deletions was the 4.5-kb Xhol-Bglll fragment previously shown to be sufficient to complement the g/1-1 deletion mutant (Oppenheimer et al., 1991). Nucleotide coordinates are given relative to the first nucleotide of the start codon, which is 1402 bp downstream of the Xhol site. The production of trichomes on the leaves of regenerating shoots provided a rapid assay
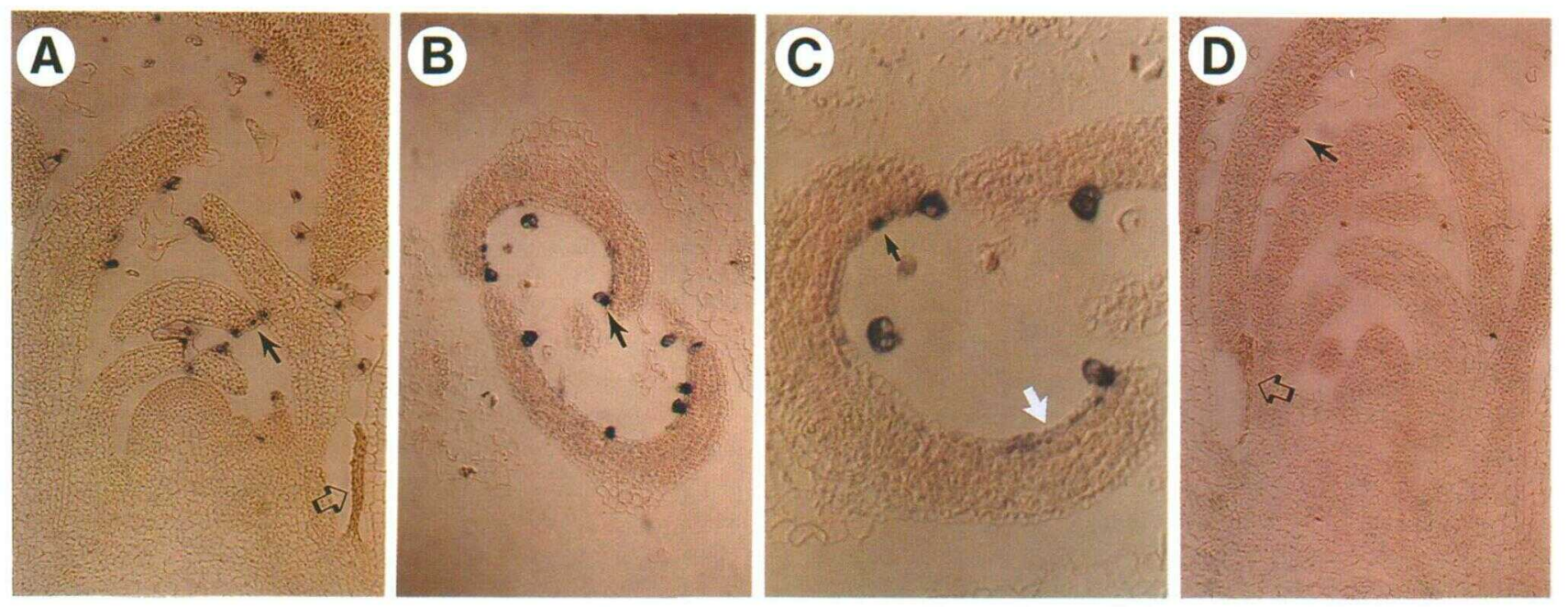

Figure 1. GL1 Transcript Distribution in Vegetative Meristems.

(A) Longitudinal section through a wild-type vegetative apex hybridized with a GL1-specific antisense probe.

(B) Cross-section through wild-type leaf primordia hybridized with a GL1-specific antisense probe.

(C) Higher magnification view of a portion of the leaf primordia shown in (B).

(D) Longitudinal section through a wild-type vegetative meristem hybridized with a GL1 sense strand control probe. Filled arrow indicates a possible trichome precursor cell.

Hybridization signals are visible as a blue-purple depositions of pigment. Filled arrows show developing trichomes; open arrows, mature stipules; and white arrow, hybridization in adaxial epidermis. 


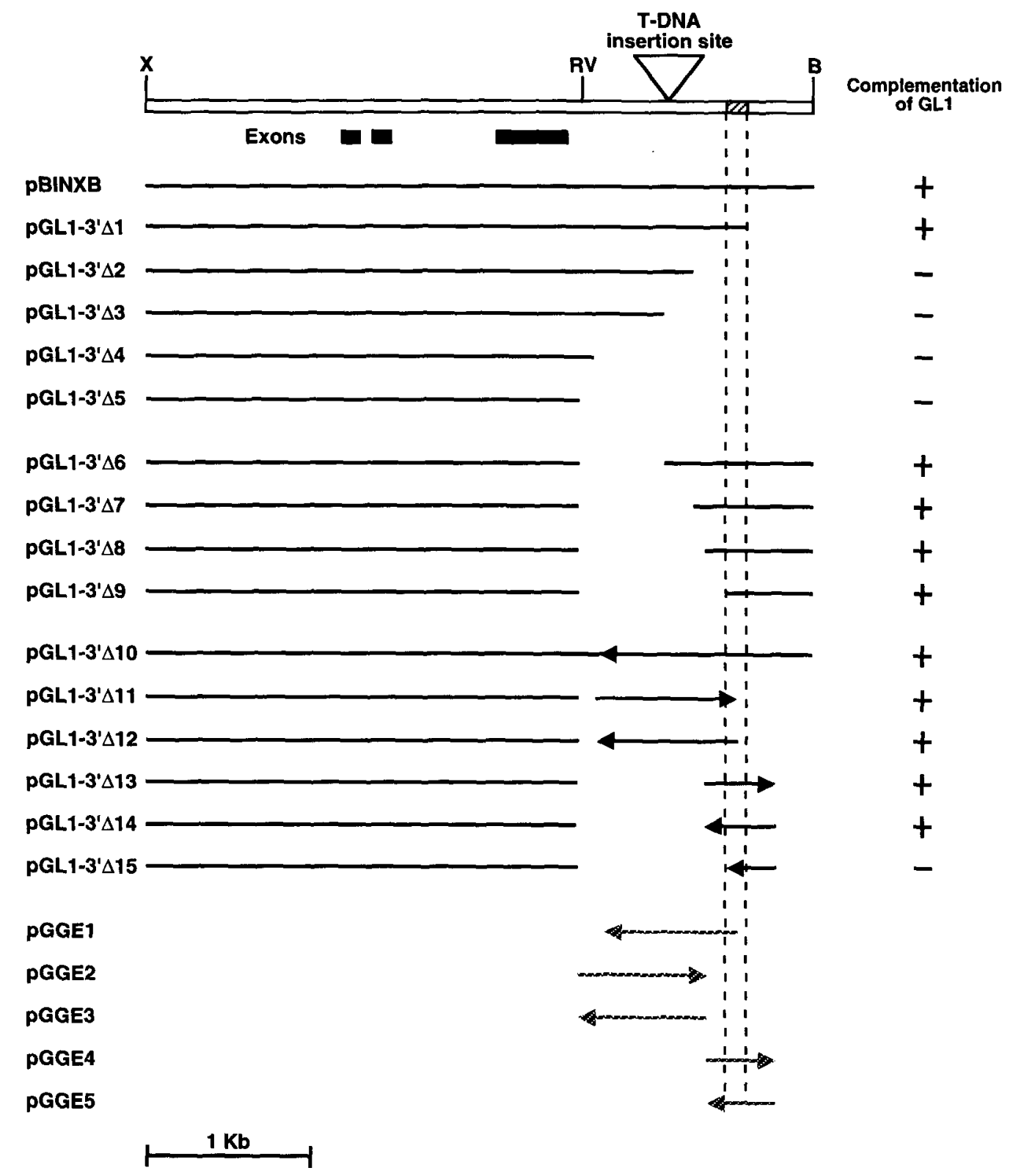

Figure 2. Diagrammatic Representation of the GL1 3' Deletion Constructs.

Sequences retained in each construct are represented by a black bar below the schematic of the GL1 locus. All of the pGL1- $3^{\prime} \triangle$ constructs contain the entire GL1 transcribed region as well as $1.4 \mathrm{~kb}$ of upstream sequences. In the pGGE constructs, various portions of the GL1 $3^{\prime}$ noncoding region have been inserted downstream of a chimeric reporter gene in which the GUS coding sequence has been placed under the control of GL1 5' sequences. In pGL1-3' $\triangle 1$ through pGL1-3' $\triangle 9$, all GL1 sequences are in the same relative orientations as in the wild-type gene. For pGL1$3^{\prime} \Delta 10$ through $p G L 1-3^{\prime} \Delta 15$ and for the PGGE constructs, the relative orientation of the GL1 $3^{\prime}$ noncoding segment present in each construct is indicated by an arrowhead. See Methods for details of plasmid constructions. Complementation results for the pGL1-3' $\Delta$ constructs are based on the ability of the construct to induce the production of trichomes on leaves of regenerating transgenic plantlets in culture (see Table 1 for data). The restriction sites indicated on the GLY schematic are X, Xhol; RV, EcoRV; B, BamHI. A hatched box indicates the region between the end points of $p G L 1-3^{\prime} \Delta 1$ and $P G L 1-3^{\prime} \Delta 9$, which must contain at least a portion of the essential downstream sequences. The positions of the three GL1 exons (black boxes) and the g/7-43 T-DNA insertion site are also indicated. Functional complementaton of the g/1-1 mutant phenotype, based on the data in Table 1 , is indicated by a + , while failure to complement g/7-1 is indicated by a - . 
for complementation of the g/1-1-conferred phenotype (Herman and Marks, 1989). The deletion constructs were used to transform g/7-1 plants and assayed for the ability to complement the mutant phenotype. The plasmid pBINXB, which contains the entire GL1 Xhol-Bglll restriction fragment, was included in each transformation experiment as a positive control.

In the first set of deletion constructs, sequences were removed progressively from the $3^{\prime}$ end of the Xhol-Bglll fragment (Figure 2, pGL1-3' $\Delta 1-p G L 1-3^{\prime} \Delta 5$ ). The proportion of regenerating shoots that produced trichomes following transformation with each of these constructs is given in Table 1. The deletion of sequences to position +2741 (pGL1-3' $\Delta 1$ ) had no effect on the ability to complement $g / 7-1$, in comparison to pBINXB transformants. In contrast, none of the regenerating shoots transformed with a construct deleted to position +2414 (pGL1$3^{\prime} \Delta 2$ ) produced trichomes (Figure 2 and Table 1). All deletions with end points upstream of this position also failed to complement git-1 efficiently (pGL1-3' $\Delta 3-p$ GL1-3' $\Delta 5$; Figure 2 and Table 1). As shown in Table 2, the analysis of transgenic plant families confirms the results of the tissue culture assay. Most of the transgenic families containing pGL1-3' $\Delta 2$, $p G L 1-3^{\prime} \Delta 3$,

Table 1. Frequency of Trichome ${ }^{+}$Shoots Regenerating from g/1-1 Mutant Explants Transformed with Various pGL1-3' $\Delta$ Constructs

\begin{tabular}{|c|c|c|}
\hline Plasmid & $\begin{array}{l}\text { No. of Kan' } \\
\text { Shoots Producing } \\
\text { Trichomes in } \\
\text { Culture } \\
\text { (trichome }^{+} / \text {total)a }\end{array}$ & $\begin{array}{l}\text { Percent of } \\
\text { Shoots } \\
\text { Producing } \\
\text { Trichomes }\end{array}$ \\
\hline pBIN19 & $0 / 45$ & 0.0 \\
\hline pGL1 & $63 / 101$ & 62.4 \\
\hline pGL1-3' $\Delta 1$ & $16 / 21$ & 76.2 \\
\hline pGL1-3' $\triangle 2$ & $0 / 42$ & 0.0 \\
\hline pGL1-3'A3 & $0 / 22$ & 0.0 \\
\hline PGL1-3' $\Delta 4$ & $5 / 44$ & $11.3^{b}$ \\
\hline pGL $1-3^{\prime} \Delta 5$ & $4 / 62$ & $6.4^{\circ}$ \\
\hline pGL1 $1-3^{\prime} \Delta 6$ & $17 / 33$ & 51.5 \\
\hline pGL1-3' $\Delta 7$ & $14 / 55$ & 25.4 \\
\hline pGL1-3' $\Delta 8$ & $21 / 39$ & 53.9 \\
\hline pGL1-3' $\triangle 9$ & $25 / 37$ & 67.6 \\
\hline pGL1-3'A10 & $4 / 11$ & 36.4 \\
\hline pGL1-3' $\Delta 11$ & $3 / 10$ & 30.0 \\
\hline pGL1-3'A12 & $22 / 46$ & 47.6 \\
\hline pGL1-3' $\Delta 13$ & $17 / 33$ & 51.5 \\
\hline pGL1-3' $\Delta 14$ & $9 / 16$ & 56.3 \\
\hline pGL1-3' $\Delta 15$ & $1 / 36$ & 2.8 \\
\hline
\end{tabular}

${ }^{a}$ Kanr, kanamycin resistant; trichome ${ }^{+}$, explants producing trichomes. The trichome phenotype of regenerating shoots transformed with various plasmids was scored 4 to 5 weeks after the explants were transferred to kanamycin-containing media.

${ }^{b}$ Four of the five trichome ${ }^{+} p G L 1-3^{\prime} \Delta 4$ regenerants produced very few trichomes.

'All four trichome ${ }^{+} \mathrm{pGL1-3} \Delta 5$ regenerants produced very few trichomes.
Table 2. Leaf Trichome Numbers on Plants from Various pGL1-3'A Transgenic Lines

\begin{tabular}{|c|c|c|c|c|}
\hline \multicolumn{2}{|c|}{ Plant Families } & $\begin{array}{l}\text { Number } \\
\text { of Inde- } \\
\text { pendent } \\
\text { Inserts }^{\mathrm{a}}\end{array}$ & $\begin{array}{l}\text { Trichomes/ } \\
\text { Leaf }( \pm S D)^{b}\end{array}$ & $\begin{array}{l}\text { Production } \\
\text { of Tri- } \\
\text { chomes } \\
\text { on Stems }\end{array}$ \\
\hline \multicolumn{2}{|c|}{ Wild type (an) } & - & $19.4 \pm 2.9$ & + \\
\hline \multirow{4}{*}{ pGLY } & A & 1 & $6.8 \pm 3.3$ & + \\
\hline & B & 1 & $16.9 \pm 2.2$ & + \\
\hline & $E$ & 1 & $9.1 \pm 2.5$ & + \\
\hline & $F$ & $2^{d}$ & $14.9 \pm 3.8$ & + \\
\hline pGL1-3' $\Delta 1$ & $D$ & 1 & $10.8 \pm 4.2$ & + \\
\hline pGL1-3' $\triangle 2$ & C & 1 & $0.0 \pm 0.0$ & - \\
\hline \multirow[t]{3}{*}{ pGL1-3' $\Delta 3$} & G & 1 & $0.0 \pm 0.0$ & - \\
\hline & $\mathrm{H}$ & 1 & $0.0 \pm 0.0$ & - \\
\hline & $\mathrm{K}$ & 1 & $0.0 \pm 0.0$ & - \\
\hline \multirow[t]{5}{*}{ pGL1-3'A5 } & $\mathrm{D}$ & 1 & $0.0 \pm 0.0$ & - \\
\hline & $F$ & 1 & $1.7 \pm 1.0$ & - \\
\hline & $\mathrm{H}$ & 1 & $0.0 \pm 0.0$ & - \\
\hline & J & 1 & $4.1 \pm 2.5$ & - \\
\hline & $K$ & 2 & $0.0 \pm 0.0$ & - \\
\hline \multirow{2}{*}{ pGL1-3'A9 } & $E$ & 1 & $12.3 \pm 2.3$ & + \\
\hline & K & 1 & $11.2 \pm 3.4$ & + \\
\hline \multicolumn{2}{|l|}{ pGL1-3'A14 C } & 1 & $18.8 \pm 3.1$ & + \\
\hline & D & 1 & $17.9 \pm 3.2$ & + \\
\hline
\end{tabular}

a The number of independently segregating inserts was determined by following both the segregation of kanamycin resistance and the production of trichomes. The presence of approximately one to three intact copies of $G L 13^{\prime} \Delta$ transgene was confirmed by DNA gel blotting. b The number of trichomes was counted on one member of the first leaf pair of 10 plants in $F_{3}$ families segregating for the insert(s). $c+$, Trichomes produced; - , trichomes not produced.

d This family was segregating for two independent kanamycinresistant inserts, but only one of the inserts was responsible for the production of trichomes.

or PGL1-3' $\Delta 5$ produced no trichomes. Those families containing $p G L 1-3$ ' $\Delta 5$ that did produce some trichomes produced many fewer trichomes than did pBINXB transformants (Table 2). These results demonstrate that sequences downstream of the $G L 1$ coding region are required for trichome initiation. The downstream boundary of these essential sequences must lie between the deletion end points of $p G L 1-3^{\prime} \Delta 1$ and $p G L 1-3^{\prime} \Delta 2$.

$A$ second deletion set was constructed removing internal sequences from the $G L 13^{\prime}$ noncoding region. A common upstream end point was maintained for these deletions at an EcoRV site located at position +1640 , which is 17 bp downstream of the first GL1 polyadenylation site. Four deletions were constructed that removed $568,774,782$, and 949 bp downstream of this EcoRV site (Figure 2, pGL1-3' $\Delta 6-p$ GL1-3' $\Delta 9$ ). All four constructs complemented the g/7-1 mutation for the production of trichomes on leaves in tissue culture (Table 1). pGL1-3' $\Delta 9$ also complemented the g/7-1 mutant phenotype in transgenic plants (Table 2). The results from this set of deletions indicate that $3^{\prime}$ sequences sufficient for $G L 1$ function must 
reside downstream of position +2589 , the end point of the pGL1-3' $\Delta 9$ deletion. At least a portion of the essential $3^{\prime}$ sequences must lie between positions +2589 and +2741 (hatched section of the GL1 3 ' noncoding region in Figure 2).

Two possible explanations must be considered regarding the nature of this essential downstream region. This region may contain a transcriptional enhancer required for the proper level and expression pattern of the GL1 transcript. Alternatively, the region might contain a coding exon missed by the original analysis of the GL1 gene. The latter hypothesis seemed unlikely because two polyadenylation sites were identified at positions +1628 and +1643 by polymerase chain reaction amplification of the $3^{\prime}$ ends of the GL1 transcript; longer transcripts were not detected (Oppenheimer et al., 1991). However, two short open reading frames (ORFs) do exist downstream of the three identified coding exons. The first of these, ORF 4 (Oppenheimer et al., 1991), is completely deleted in the pGL1$3^{\prime} \Delta 9$ construct, which acts as a functional GL1 gene. The second downstream ORF (ORF 5 ) is located between the end points of $p G L 1-3^{\prime} \Delta 1$ and $p G L 1-3^{\prime} \Delta 2$, which is within the region required for $G L 1$ function.

To test for the presence of a transcriptional enhancer and to further localize the sequences required for $G L 1$ function, several additional constructs were generated containing alterations of the $3^{\prime}$ noncoding region (Figure 2). A required exon would not function in the inverse orientation, whereas an enhancer would be expected to function after inversion. In the plasmid pGL1-3' $\Delta 10$, all of the sequences downstream of position + 1739 were inverted, and no sequences were deleted (Figure 2). In addition, sequences from three regions, +1795 to +2705 (pGL1-3' $\Delta 11$ and pGL1-3' $\Delta 12$ ), +2423 to +2914 (pGL1-3' $\Delta 13$ and pGL1-3' $\Delta 14$ ), and +2589 to +2914 (pGL1$\left.3^{\prime} \Delta 15\right)$ were inserted downstream of the EcoRV site at +1640 in both orientations (Figure 2). The pGL1-3' $\Delta 10$, pGL1-3' ${ }^{\prime} \Delta 11$, pGL1-3' $\Delta 12$, pGL1-3' $\Delta 13$, and pGL1-3' $\Delta 14$ constructs complemented the g/7-1 mutation (Figure 2 and Tables 1 and 2). Thus, the sequences between +2423 and +2914 downstream of the $G L 1$ coding region, in either orientation, are both necessary and sufficient to function as the essential downstream element. However, because the pGL1-3' $\Delta 15$ construct does not complement g/1-1, the sequences between +2589 and +2914 are not sufficient for function, at least when present in an inverted orientation.

\section{Sequences from the $3^{\prime}$ Noncoding Region Extend the Expression Pattern of the GL1 Promoter-GUS Fusion Construct}

Several portions of the GL1 $3^{\prime}$ noncoding region were inserted downstream of the GUS reporter gene in the plasmid pGL1p/ GUS to examine whether these sequences would alter the stipule-specific expression pattern. The GUS histochemical staining patterns observed in plants that contain these pGGE (GL1-GUS Enhancer) reporter gene constructs are listed in Table 3. A variety of sequences from the $3^{\prime}$ end of the GL1 gene resulted in the expression of GUS activity in leaf primordia and developing trichomes in addition to expression in stipules, as shown in Figure 3. These sequences are also able to direct the expression of GUS activity in leaf primordia and developing trichomes regardless of orientation. Aberrant staining patterns were exhibited by two of 17 families, presumably due to the influence of sequences near the insertion site (Topping et al., 1991). GUS activity was initially expressed throughout the leaf primordium (Figure 3A). In transgenic plants from families with somewhat lower overall expression levels, the highest levels of GUS activity were observed in developing trichomes (Figure 3B, open arrow). In older leaves of plants from families exhibiting high levels of expression, GUS activity persisted longest in the trichomes (Figure $3 \mathrm{C}$ ). GUS activity was also detected in the stem and stem trichomes of bolting plants (Figure 3D). The staining visible within the developing flower buds in Figure 3D is due to weak staining in developing stamens and carpels (data not shown). As expected, in plants transformed with the original pGL1p/GUS plasmid, GUS activity was only detected in stipules (Figure 3E, filled arrow).

Transgenic plants containing the constructs pGGE2 and pGGE3 exhibit histochemical staining for GUS activity in leaf primordia and developing trichomes in addition to expression

\begin{tabular}{|c|c|c|c|}
\hline Construct & $\begin{array}{l}\text { No. of } \\
\text { Trans- } \\
\text { formants }\end{array}$ & $\begin{array}{l}\text { Expression } \\
\text { Pattern }\end{array}$ & $\begin{array}{l}\text { Variation among } \\
\text { Transformants }^{\mathrm{a}}\end{array}$ \\
\hline pGL1p/GUS & 4 & Stipules only & - \\
\hline pGGE 1 & 2 & $\begin{array}{l}\text { Leaf primordia, } \\
\text { trichomes, } \\
\text { and stipules }\end{array}$ & $\begin{array}{l}\text { One shows faint } \\
\text { staining in } \\
\text { lateral root } \\
\text { primordia in } \\
\text { addition to leaf } \\
\text { primordia, } \\
\text { trichomes, and } \\
\text { stipules }\end{array}$ \\
\hline pGGE2 & 3 & $\begin{array}{l}\text { Leaf primordia, } \\
\text { trichomes, } \\
\text { and stipules }\end{array}$ & - \\
\hline pGGE3 & 4 & $\begin{array}{l}\text { Leaf primordia, } \\
\text { trichomes, } \\
\text { and stipules }\end{array}$ & $\begin{array}{l}\text { One shows strong } \\
\text { staining in } \\
\text { most of the } \\
\text { seedling, } \\
\text { especially } \\
\text { vascular tissue }\end{array}$ \\
\hline pGGE4 & 6 & $\begin{array}{l}\text { Leaf primordia, } \\
\text { trichomes, } \\
\text { and stipules }\end{array}$ & - \\
\hline PGGE5 & 4 & $\begin{array}{l}\text { Leaf primordia } \\
\text { trichomes, } \\
\text { and stipules }\end{array}$ & - \\
\hline
\end{tabular}

\footnotetext{
a -, No variation among transformants, except for minor variations in staining intensity.
} 

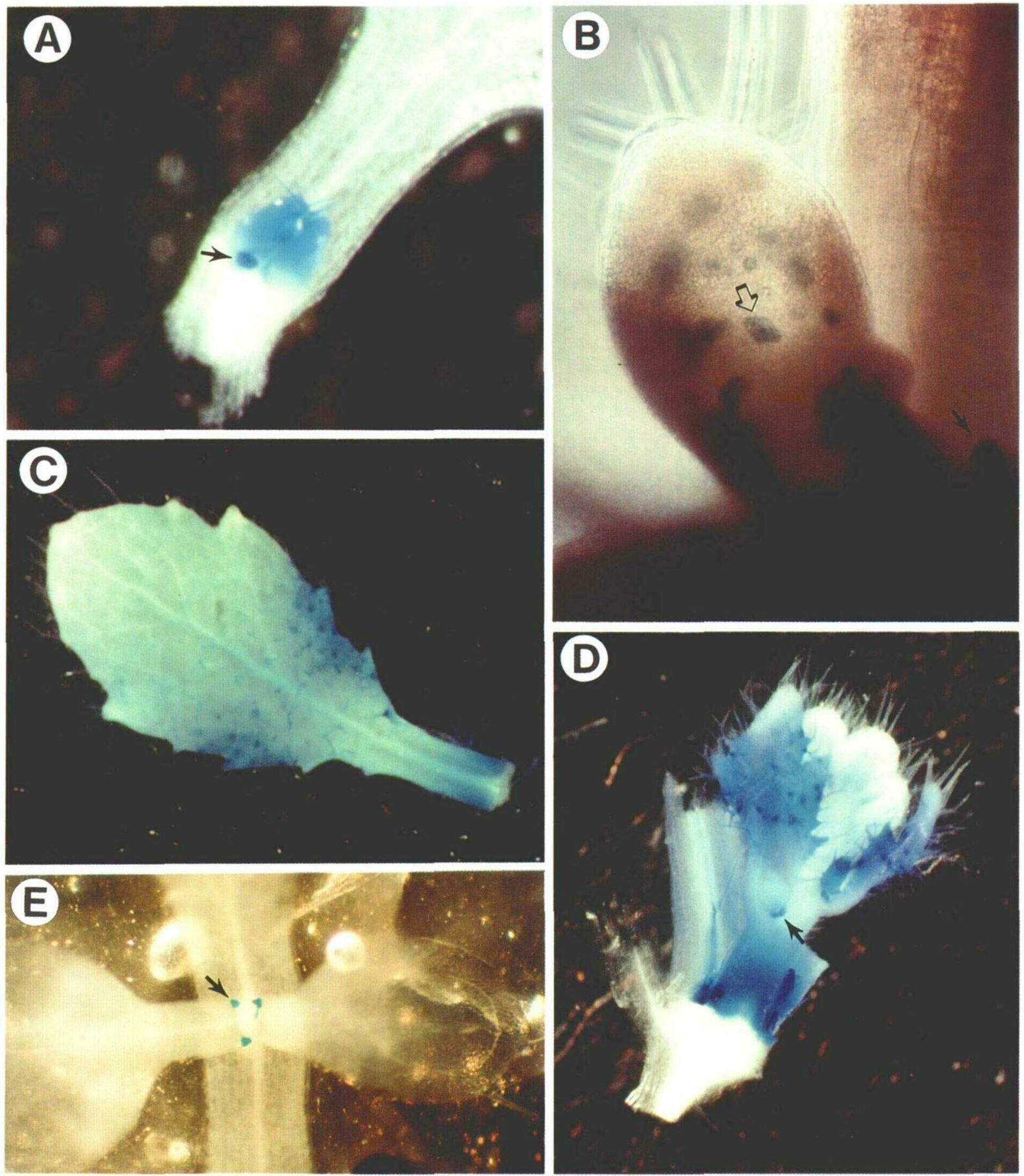

Figure 3. Addition of GL1 Downstream Sequences to pGL1p/GUS Increases the Range of the GUS Expression Pattern.

(A) Young seedling apex of a pGGE5 plant stained with X-gluc.

(B) Leaf primordium of a pGGE1 plant stained with X-gluc.

(C) Older leaf of a pGGE5 plant stained with X-gluc.

(D) Stem and inflorescence of a bolting pGGE5 plant stained with X-gluc.

(E) Seedling of a pGL1p/GUS plant stained with X-gluc.

Filled arrows in (A), (B), (D), and (E) indicate stipules. The open arrow in (B) indicates a developing trichome. 
in stipules. However, these constructs do not include the region identified above as essential for GL1 function (Figure 2 and Table 1). In an attempt to resolve this inconsistency, we performed quantitative assays for GUS activity on transgenic seedlings containing various PGGE constructs, as shown in Table 4. The levels of GUS activity detected were quite low, with the highest levels only five- to eightfold above background levels observed in untransformed plants. However, these higher levels of GUS activity were detected only in pGGE4 and pGGE5 transformants, which contain downstream sequences that are required for GL1 function. In contrast, all pGL1p/GUS, pGGE2, and pGGE3 transformed families examined exhibited lower levels of GUS activity (Table 4).

\section{DISCUSSION}

Our previous work demonstrated that sequences $5^{\prime}$ to the GL1 gene direct the expression of a GUS reporter gene only in the stipules of developing leaf primordia. However, in this work, we show that GL1 transcripts are most abundant in leaf primordia and developing trichomes. In addition, we have shown that sequences more than 900 bp downstream of the $3^{\prime}$ end of the GL1 transcript contain an enhancer-like element essential for trichome initiation. Sequences from the same 490-bp region downstream of $G L 1$, in conjunction with $G L 15$ ' sequences, direct the expression of a GUS reporter construct in stipules, leaf primordia, and developing trichomes. The pattern of GUS activity observed in plants containing the pGGE constructs is very similar to the distribution of GL1 transcripts detected by in situ hybridization (compare Figures $1 \mathrm{~A}$ and $1 \mathrm{~B}$ with Figure $3 B)$. Thus, the same downstream region that is required for GL1 function also acts as an enhancer-like element that confers the proper GL1 expression pattern on a GUS reporter gene construct. These results strongly suggest that the expression of $G L 1$ in leaf primordia and developing trichomes is essential for $G L 1$ function.

We have not examined the nature of the interaction between the $5^{\prime}$ and $3^{\prime}$ noncoding sequences of $G L 1$ in promoting

Table 4. GUS Activity Levels in Various pGGE Transgenic Lines

\begin{tabular}{lll}
\hline Construct & $\begin{array}{l}\text { No. of } \\
\text { Transformants }\end{array}$ & $\begin{array}{l}\text { GUS } \\
\text { Activity }^{\mathrm{a}}\end{array}$ \\
\hline pGL1p/GUS & 2 & 0.2 \\
pGGE2 & 3 & $0.7 \pm 0.2$ \\
pGGE3 & 3 & $0.6 \pm 0.02$ \\
pGGE4 & 5 & $1.2 \pm 0.4$ \\
pGGE5 & 4 & $2.9 \pm 0.8$ \\
\hline
\end{tabular}

a Data are presented as the mean \pm SE of the GUS activities (pmol 4-methylumbelliferone/min/mg protein) in tissue extracts from equivalently staged seedlings from independent transformants. expression of the reporter gene in leaf primordia and developing trichomes. Thus, we cannot yet distinguish whether the 3 ' sequences contain a true tissue-specific enhancer or a constitutive enhancer acting through the GL1 5' sequences. Experiments to discriminate between these possibilities are in progress.

We have not been able to detect high levels of GL1 transcripts in stipules, despite the high levels of GUS activity detected in the stipules of plants containing pGL1p/GUS or the pGGE constructs. It seems unlikely that the histochemical localization of GUS activity in stipules is artifactual. The tissue was prefixed in $0.1 \%$ formaldehyde to prevent the induction of enzyme activity during the assay, and $\mathrm{K} / \mathrm{Fe}\left(\mathrm{CN}_{6}\right)$ was included in the assay buffer to promote the in situ precipitation of the indigo blue precipitate (De Block and Debrouwer, 1992). One possible explanation for our failure to detect $G L 1$ transcripts in older stipules may be that RNA in stipules is less accessible to hybridization. Arabidopsis stipules appear to be glandular and rather different from the surrounding tissues in their histological properties. We have been unable to detect GL1 transcripts in the stipules of plants containing a GL1 coding region under the control of the cauliflower mosaic virus (CaMV) 35S promoter, whereas high levels of the GL1 transcript were detected in all surrounding tissues (D.G. Oppenheimer, unpublished observations). In contrast, the $35 \mathrm{~S}$ promoter drives GUS expression at high levels in both stipules and the surrounding tissues.

Another minor difference between the pattern of $G L 1$ transcript accumulation and the pattern of GUS activity in the pGGE constructs is that GUS activity is detected in all cell layers of the developing leaf primordium, whereas the strongest in situ hybridization signals are detected in the protoderm. However, in older leaves, in which the GUS histochemical staining of nontrichome cells has become weaker, preferential staining of the epidermis has been observed (J.C. Larkin, unpublished data). It seems likely that differences in the relative stabilities of the GL1 transcript and the GUS protein (and/or transcript) contribute to the minor differences that we have observed between the in situ hybridizations and the GUS histochemical staining patterns. However, we cannot rule out the possibility that additional regulatory sequences are located within the transcribed region of GL1.

Several lines of evidence suggest that the $3^{\prime}$ enhancer contains functionally redundant sequences. First, the pGL1-3' $\Delta 1$ and $p G L 1-3^{\prime} \Delta 9$ deletion constructs define a 152-bp region between positions +2589 and +2741 that must contain at least a portion of the essential sequences (hatched section of the GL1 $3^{\prime}$ noncoding region in Figure 2). However, pGL1-3' $\Delta 15$, which contains downstream sequences from +2589 to +2913 , fails to complement git-1. pGL1-3' $\Delta 9$ has the same upstream end point as pGL1-3' $\Delta 15$, but contains additional downstream sequences, whereas pGL1-3' $\Delta 13$ and $p G L 1-3^{\prime} \Delta 14$ have the same downstream end point as pGL1-3' $\Delta 15$ but contain additional upstream sequences. All three of these constructs complement g/7-1, indicating that the addition of sequences either upstream of +2589 or downstream of +2913 to the 
sequences present in pGL1- $3^{\prime} \Delta 15$ is sufficient to restore function. Additional evidence for functional redundancy comes from the pGGE results (Table 3 ).

The GL1 $3^{\prime}$ noncoding sequences present in pGGE2 and pGGE3 do not overlap with the 3 ' sequences present in pGGE4 and PGGE5, yet all of these constructs direct GUS expression in leaf primordia and developing trichomes. The downstream region contained in the pGGE2 and pGGE3 constructs is not required for or sufficient for $G L 1$ function. Consistent with these observations, pGGE4 and pGGE5 transformants have higher levels of GUS activity than pGGE2 and pGGE3 transformants in quantitative GUS assays (Table 4). Thus, it is possible that a combination of several equivalent copies of a leaf primordia/trichome-specific enhancer is required to raise the level of $G L 1$ expression to some functional threshold. Similar results have been obtained with other plant transcriptional regulatory sequences (Leyva et al., 1992).

We have not detected any stem-specific regulatory elements that could be responsible for the phenotype of the g/1-43 T-DNA insertion allele during our analysis of the GL1 $3^{\prime}$ regulatory region. As described above, plants homozygous for this allele have normal leaf trichomes but lack trichomes on stems. All of the deletion constructs generated here affect both leaf and stem trichomes (Table 2). It seems likely that the phenotype of the g/7-43 mutant allele is the result of the novel sequences inserted downstream of the gene, rather than the result of the disruption of existing $G L 1$ regulatory sequences that are specific to stem trichomes. Alternatively, subtle interactions between subdomains of the $3^{\prime}$ regulatory region may have been missed by this analysis. However, it should be noted that pGL1$3^{\prime} \Delta 9$ removes sequences from 584 bp upstream of the g/1-43 T-DNA insertion site to 365 bp downstream of the insertion site and has no effect on trichome development. Thus, it seems unlikely that a stem-specific regulatory sequence is located in this region.

Many examples of enhancers located downstream of the transcription initiation site are known in animal systems (Choi and Engel, 1986; Fischer and Maniatis, 1986). A particularly striking example is provided by the mouse erythropoietin gene (Pugh et al., 1991). An enhancer located 3' of the polyadenylation site of this gene directs oxygen-regulated transcription even in constructs removing the normal transcription start site. In plants, several instances of enhancers or enhancer-like sequences that can function $3^{\prime}$ of the transcription start site have been identified. The CaMV enhancer is able to function when placed downstream of a reporter gene (Nagy et al., 1987). Similarly, an enhancer from the $5^{\prime}$ noncoding region of a soybean $\beta$-conglycinin gene can confer seed-specific expression on the CaMV 355 promoter when located between the reporter gene coding region and the polyadenylation site but not when located downstream of the polyadenylation site (Chen et al., 1988). Both of these enhancers function more effectively when located $5^{\prime}$ of the gene. Dean et al. (1989) have shown that sequences located $3^{\prime}$ of the coding region of petunia ribulose bisphosphate carboxylase small subunit genes influence the rates of transcription of the genes. Sequences located within or near the coding region and required for the full range of expression have been described for the pea ferredoxin I gene (Elliot et al., 1989), a parsley 4-coumarate:coenzyme A ligase gene (Douglas et al., 1991), and the oilseed rape AX92 gene (Dietrich et al., 1992), although none of these sequences has been shown to function as a transcriptional enhancer.

The in situ hybridization results, in conjunction with the expression pattern of the reporter gene constructs, indicate that GL1 is initially expressed throughout the leaf primordium, with higher transcript levels in the protoderm. However, much higher transcript levels are seen in developing trichomes. In fact, high levels of $G L 1$ transcripts are detected in some protodermal cells that have not shown any sign of cell expansion (Figure 1C, solid arrow). Thus, it appears that a rapid increase in the $G L 1$ transcript level is an early event in the commitment of a protodermal cell to the trichome development pathway. In some respects, this observation is reminiscent of the pattern of scute expression during sensory bristle formation in Drosophila (reviewed in Ghysen et al., 1993). Expression of scute is initially detected in a field of cells but ultimately becomes restricted to a single "sensory mother cell" expressing high levels of scute transcripts and protein. This comparison with the well-studied bristle development system in Drosophila brings into focus an important unanswered question about the trichome developmental pathway: How are the trichome precursor cells selected? The continued analysis of the control of GL1 expression, in conjunction with the study of other components of the trichome developmental pathway, should provide a model for understanding the commitment of plant cells to specific developmental fates.

\section{METHODS}

\section{In Situ Hybridization}

The template for the in situ hybridization probe was derived from pGL1ex04.9. This exonuclease III-generated deletion (Oppenheimer et al., 1991) completely removes the myb DNA binding region of GLABROUS1 (GL1) and leaves the single-copy, carboxy-terminal domain of the protein-coding region. The pGL1ex04.9 clone was digested with SstII and religated to remove the majority of the $G L 13^{\prime}$ noncoding region. This clone was called pGL1C3. The template for the production of digoxygenen-UTP-labeled RNA probes by runoff transcription was BssHII-digested pGL1C3. T3 RNA polymerase was used to generate antisense strand $G L 1$ probes, and T7 RNA polymerase was used to generate sense strand $G L 1$ probes, using components obtained from Boehringer Mannheim. Plant tissue was fixed, dehydrated, and embedded in paraffin essentially as described by Jackson (1991). Sections, 8- $\mu \mathrm{m}$ thick, were cut and mounted on poly-L-lysine-coated slides and processed essentially as described by Drews et al. (1991), except that the BMB blocking reagent from a Genius kit (Boehringer Mannheim) was substituted for Denhardt's solution. After washing the slides, they were processed and developed as recommended in the Genius kit. Slides were allowed to develop 1 to 3 days before photographing.

\section{Construction of $\mathbf{3}^{\prime}$ Deletions}

The starting point for the construction of deletions of the GL1 downstream region was the plasmid pGL1 (Oppenheimer et al., 1991). This 
plasmid contains the 4.5-kb Xhol-Bglll fragment of GL1 inserted into the Xhol and BamHI sites of the vector pBluescriptll SK+ (Stratagene). To generate nested deletions from the $3^{\prime}$ end, the Xhol-Hhal (pGL1$3^{\prime} \Delta 1$, deletion end point +2741 ), Xhol-Dralll ( $p$ GL1-3' $\Delta 2$, deletion end point +2414 ), Xhol-Nrul (pGL1-3' $\Delta 3$, deletion end point +2208 ), XholSstll (pGL1-3' $\triangle 4$, deletion end point +1740 ), and Xhol-EcoRV (pGL1$3^{\prime} \Delta 5$, deletion end point +1641 ) restriction fragments from $p G L 1$ were each cloned into Sall, Smal-cut pBIN19 (Bevan, 1984). The Sstll and Hhal ends were rendered blunt with T4 polymerase before ligation, according to the manufacturer's instructions (New England Biolabs, Beverly, MA).

The internal deletions of the GLY 3 ' end were generated by cutting pGL1 with EcoRV and Sstl (a vector site), treating the plasmid with calf intestinal phosphatase (Boehringer Mannheim), and inserting various isolated restriction fragments. The fragments used were the Nrul-Sstl (pGL1-3' $\Delta 6$ ), Dralll-Sstl (pGL1-3' $\Delta 7$ ), EcoRV-Sstl (pGL1-3' $\Delta 8$ ), and Hincll-Sstl (pGL1-3' $\Delta 9$ ) fragments. The sequences deleted in these constructs are pGL1-3' $\Delta 6,+1641$ to $+2208 ;$ pGL1-3' $\Delta 7,+1641$ to +2414 ; pGL1-3' $\Delta 8,+1641$ to +2422 ; and pGL1-3' $\Delta 9,+1641$ to +2488 . In a similar manner, the $p G L 1-3^{\prime} \Delta 11$ through pGL1-3' $\Delta 15$ constructs were generated by ligating the following restriction fragments from the $G L 1$ downstream region to EcoRV, Xbal-cut pGL1, where the Xbal site had been filled in with T4 DNA polymerase: the 911-bp Dral fragment (pGL1$3^{\prime} \Delta 11$ and $p G L 1-3^{\prime} \Delta 12,+1795$ to +2415 ), the $490-b p$ EcoRV-Accl fragment (pGL1-3' $\Delta 13$ and pGL1-3' $\Delta 14,+2423$ to +2913 ), and the 324-bp Hincll-Accl fragment (pGL1-3' $\Delta 15,+2489$ to +2913 ). The pGL1-3' $\Delta 10$ construct was generated by inverting the Sstll fragment of pGL1. The pGL1-3' $\Delta 6$ through pGL1-3' $\Delta 15$ constructs were excised from the pBluescriptll SK+ vector with Xhol and Sstl and inserted between the Sall and Sstl sites of pBIN19. The plasmids were transferred to Agrobacterium tumefaciens LBA4404 (Hoekema et al., 1983; An et al., 1988) by electroporation.

\section{Construction of pGL1p/GUS Enhancer Plasmids}

The plasmid pGL1p/GUS (Oppenheimer et al., 1991) contains $1.4 \mathrm{~kb}$ of $G L 15^{\prime}$ noncoding sequence fused to the $\beta$-glucuronidase (GUS) coding region of $\mathrm{pBl} 101$ (Jefferson et al., 1987). The pGGE plasmids were constructed by ligating restriction fragments from PGL1 into the EcoRI site (filled in with T4 polymerase and deoxynucleotides) that is located downstream of the nopaline synthetase terminator of pGL1p/GUS. The restriction fragments used were the 911-bp Dral fragment (pGGE1), the 782-bp EcoRV fragment (pGGE2 and pGGE3), and the 490-bp EcoRV-Accl fragment (pGGE4 and pGGE5).

\section{Plant Transformation}

Arabidopsis thaliana root explants were transformed and regenerated as described previously (Feldmann and Marks, 1986; Valvekens et al., 1988; Oppenheimer et al., 1991). The pGGE plants were regenerated from explants of the Wassileskija genotype (WS). Most of the g/7-1 mutant explants that were transformed with the $3^{\prime}$ deletion constructs were of the genotype gil-1, an in a Columbia genetic background (Oppenheimer et al., 1991). A few experiments were conducted with explants from plants in which the g/1-1 mutation had been backcrossed three times into the WS background, which yields transformants at a much higher frequency. No differences between the two genotypes in the frequency of explants producing trichomes were observed in control experiments. Data on the proportion of regenerating explants producing trichomes from both backgrounds are pooled in Table 1. In each transformation experiment, pBINXB-transformed explants were included as positive controls. In most experiments, pGL1-3' $\Delta 5$-transformed explants were included as negative controls.

All of the transgenic plant families described in Table 2 were regenerated from the g/1-1, an background. The number of independent inserts was determined by following the segregation of both kanamycin resistance and trichome phenotype. The presence of approximately one to three intact copies of the transgene in each family was confirmed by DNA gel blotting. Trichome counts given in Table 2 were determined by counting the number of trichomes on one member of the first leaf pair of T3 seedlings in families segregating for the insert(s), as described in Table 2.

\section{Histochemical and Quantitative GUS Assays}

Plant tissue was prefixed under vacuum in $0.1 \%$ formaldehyde, 100 $\mathrm{mM} \mathrm{NaPO}, \mathrm{pH} 7.0,0.1 \%$ Triton X-100, rinsed in $50 \mathrm{mM} \mathrm{NaPO}_{4}, \mathrm{pH}$ 7.0 , and immersed in $1 \mathrm{mg} / \mathrm{mL} 5$-bromo-4-chloro-3-indoyl glucuronide (X-gluc), $1 \mathrm{mM} \mathrm{K}_{3} \mathrm{Fe}\left(\mathrm{CN}_{6}\right), 0.1 \%$ Triton X-100, $50 \mathrm{mM} \mathrm{NaPO}_{4}, \mathrm{pH} 7.0$, at $37^{\circ} \mathrm{C}$ for 6 to $18 \mathrm{hr}$ (Jefferson et al., 1987; De Block and Debrouwer, 1992). After staining, the tissue was fixed in $3.6 \%$ formaldehyde, $5 \%$ acetic acid, $50 \%$ ethanol for $15 \mathrm{~min}$ under vacuum, cleared in $95 \%$ ethanol at $65^{\circ} \mathrm{C}$ for $5 \mathrm{~min}$, and rehydrated through an ethanol series. Tissue samples were stored at $4^{\circ} \mathrm{C}$ in $10 \mathrm{mM}$ Tris- $\mathrm{HCl}, 1 \mathrm{mM}$ EDTA before undergoing photomicroscopy. For quantitative GUS assays, pooled seedlings of each genotype were ground to a powder in liquid $\mathrm{N}_{2}$ and homogenized in extraction buffer $\left(50 \mathrm{mM} \mathrm{NaPO}_{4}, \mathrm{pH} 7.0\right.$, $1 \mathrm{mM}$ EDTA, $0.1 \%$ Triton X-100, $0.1 \%$ sarkosyl, $10 \mathrm{mM} \beta$-mercaptoethanol). After centrifuging for $10 \mathrm{~min}$ in a microcentrifuge, the samples were frozen at $-70^{\circ} \mathrm{C}$. Aliquots of these samples were assayed for GUS activity in extraction buffer containing $1 \mathrm{mM}$ 4-methylumbelliferyl $\beta$-D-glucuronide, as described by Jefferson et al. (1987). Fluorescence was measured in a minifluorometer (model No. TKO100; Hofer, San Francisco, CA).

\section{ACKNOWLEDGMENTS}

J.C.L. and D.G.O. have contributed equally to the work presented. We wish to thank Dr. David Jackson (USDA Plant Gene Expression Center, Albany, CA) and Dr. Gary Drews (University of Utah, Salt Lake City) for advice on in situ hybridizations. We would also like to thank Marcia Duggan for the preparation of Figure 2. This work was supported by Grant No. DCB 9118306 from the National Science Foundation.

Received July 15, 1993; accepted October 1, 1993.

\section{REFERENCES}

An, G., Ebert, P.R., Mitra, A., and Ha, S.B. (1988). Binary vectors. In Plant Molecular Biology, G.B. Gelvin and R.A. Schilperoort, eds (Dordrecht, The Netherlands: Kluwer), pp. 1-19.

Bevan, M.W. (1984). Binary Agrobacterium vectors for plant transformation. Nucl. Acids Res. 12, 8711-8721.

Chen, Z.-L., Pan, N.-P., and Beachy, R.N. (1988). A DNA sequence element that confers seed-specific enhancement to a constitutive promoter. EMBO J. 7, 297-302. 
Chol, O.R., and Engel, J.D. (1986). A $3^{\prime}$ enhancer is required for temporal and tissue specific transcriptional activation of the chicken adult $\beta$-globin gene. Nature 323, 731-734.

Dean, C., Favreau, M., Bond-Nutter, D., Bedbrook, J., and Dunsmuir, P. (1989). Sequences downstream of translation start regulate quantitative expression of two petunia rbcS genes. Plant Cell 1, 201-208.

De Block, M., and Debiouwer, D. (1992). In-situ enzyme histochemistry on plastic-embedded plant material. The development of an artifactfree $\beta$-glucuronidase assay. Plant J. 2, 261-266.

Dietrich, R.A., Radke, S.E., and Harada, J.J. (1992). Downstream DNA sequences are required to activate a gene expressed in the root cortex of embryos and seedlings. Plant Cell 4, 1371-1382.

Douglas, C.J., Hauffe, K.D., Ites-Morales, M., Ellard, M., Paszkowski, U., Hahlbrock, K., and Dangl, J.L. (1991). Exonic sequences are required for elicitor and light activation of a plant defense gene, but promoter sequences are sufficient for tissue specific expression. EMBO J. 10, 1767-1775.

Drews, G.N., Bowman, J.L., and Meyerowitz, E.M. (1991). Negative regulation of the Arabidopsis homeotic gene AGAMOUS by the APETELA2 product. Cell 65, 991-1002.

Ellott, R.C., Dickey, L.F., White, M.J., and Thompson, W.F. (1989). cis-Acting elements for light regulation of pea ferredoxin I gene expression are located within transcribed sequences. Plant Cell 1, 691-698.

Feldmann, K.A., and Marks, M.D. (1986). Rapid and efficient regeneration of plants from explants of Arabidopsis thaliana. Plant Sci. 47, 63-67.

Fischer, J.A., and Manlatis, T.A. (1986). Regulatory elements involved in Drosophila Adh gene expression are conserved in divergent species and separate elements mediate expression in different tissues. EMBO J. 5, 1275-1289.

Ghysen, A., Dambly-Chaudlere, C., Jan, L.Y., and Jan, Y.-N. (1993). Cell interactions and gene interactions in peripheral neurogenesis. Genes Dev. 7, 723-733.

Haughn, G.W., and Somerville, C.R. (1988). Genetic control of morphogenesis in Arabidopsis. Dev. Genet. 9, 73-89.

Herman, P.L., and Marks, M.D. (1989). Trichome development in Arabidopsis thaliana. II. Isolation and complementation of the GLABROUS1 gene. Plant Cell 1, 1051-1055.

Hoekema, A., Hirsch, P.R., Hooykaas, P.J.J., and Schilperoort, R.A. (1983). A binary plant vector strategy based on separation of virand T-region of the Agrobacterium tumefaciens Ti-plasmid. Nature $303,179-180$.

Jackson, D. (1991). In situ hybridization in plants. In Molecular Plant Pathology: A Practical Approach, D.J. Bowles, S.J. Gurr, and M. McPherson, eds (Oxford: Oxford University Press), pp. 163-174.

Jefferson, R.A., Kavanagh, T.A., and Bevan, M.W. (1987). GUS fusions: $\beta$-Glucuronidase as a sensitive and versatile gene fusion marker in higher plants. EMBO J. 6, 3901-3907.
Koornneef, M., Dellaert, S.W.M., and van der Veen, J.H. (1982). EMSand radiation-induced mutation frequencies at individual loci in Arabidopsis thaliana (L.) Heynh. Mut. Res. 93, 109-123.

Larkin, J.C., Oppenheimer, D.G., and Marks, M.D. (1993). The GL1 gene and the trichome developmental pathway in Arabidopsis thaliana. In Plant Transcription Factors, L. Nover and E. Dennis, eds (Berlin: Springer-Verlag), in press.

Leyva, A., Liang, X., Pintor-Toro, J.A., Dixon, R.A., and Lamb, C.J. (1992). cis-Element combinations determine phenylalanine ammonialyase gene tissue-specific expression patterns. Plant Cell 4, 263-271.

Marks, M.D., and Esch, J. (1993). Morphology of normal and mutant trichomes and their development on the leaves of Arabidopsis thaliana. In Arabidopsis: An Atlas of Morphology and Development, J. Bowman, ed (Berlin: Springer-Verlag), in press.

Marks, M.D., and Feldmann, K.A. (1989). Trichome development in Arabidopsis thaliana. I. T-DNA tagging of the GLABROUS1 gene. Plant Cell 1, 1043-1050.

Marks, M.D., Esch, J., Herman, P., Sivakumaran, S., and Oppenheimer, D.G. (1991). A model for cell-type determination and differentiation in plants. In Molecular Biology of Plant Development, G. Jenkins and W. Schuch, eds (Cambridge: Company of Biologists Ltd), pp. 77-87.

McDaniel, C.N. (1985). Competence, determination, and induction in plant development. In Pattern Formation: A Primer in Developmental Biology, G.M. Malacinski and S. V. Bryant, eds (Now York: Macmillan), pp. 393-412.

Nagy, F., Boutry, M., Hsu, M.-H., Wong, M., and Chua, N.-H. (1987). The 5'-proximal region of the wheat Cab-1 gene contains a 268-bp enhancer-like sequence for phytochrome response. EMBO J. 6, 2537-2542.

Oppenheimer, D.G., Herman, P.L., Sivakumaran, S., Esch, J., and Marks, M.D. (1991). A myb gene required for leaf trichome differentiation in Arabidopsis is expressed in stipules. Cell 67, 483-493.

Pugh, C.W., Tan, C.C., Jones, R.W., and Ratcliffe, P.J. (1991). Functional analysis of an oxygen-regulated transcriptional enhancer lying 3 ' to the mouse erythropoietin gene. Proc. Natl. Acad. Sci. USA 88, 10553-10557.

Slack, J.M.V. (1983). From Egg to Embryo, Determinative Events in Early Development. (Cambridge: Cambridge University Press).

Topping, J.F., Wei, W., and Lindsey, K. (1991). Functional tagging of regulatory elements in the plant genome. Development 112, 1009-1019.

Valvekens, D., Van Montagu, M., and van Lijsebettens, M. (1988). Agrobacterium tumefaciens-mediated transformation of Arabidopsis thaliana root explants by using kanamycin selection. Proc. Natl. Acad. Sci. USA 85, 5536-5540. 